\title{
CELLULAR IMMUNE RESPONSE IN RAINBOW TROUT (Oncorhynchus mykiss): FLOW CYTOMETRIC STUDY
}

\author{
CHILMONCZYK S., MONGE D. \\ INRA Unité de Virologie et Immunologie Moleculaires, Jouy en Josas, France
}

Received September 15, 1998

Accepted September 21, 1998

\begin{abstract}
Chilmonczyk, S.. D. Monge: Cellular Immune Response in Rainbow Trout (Oncorhynchus mykiss): Flow Cytometric Study. Acta vet. Brno 1998, 67: 207-213.

Assays devoted to the study of non-specific cellular defense mechanisms of rainbow trout: phagocytosis, oxidative burst and nonspecific cytotoxicity, were developed. Compared to conventional methodologies flow cytometry provides a rapid, suitable and reproducible method for analysing fish cellular immune functions. In addition to the assessment of the defense mechanisms interesting data are directly provided from the observation of unstained cells. Flow cytometric profiles of cells are representative of the organ from which the leukocytes originated and each lymphoid organ displays a characteristic cytogram pattern. Flow cytometry emerges as a useful tool to study immune reactions and pathogenic processes.
\end{abstract}

Flow cytometry, rainbow trout. leukocytes, phagocytosis, oxidative burst, nonspecific cytotoxic cells

Flow cytometry (FCM) allows a cell by cell qualitative and quantitative analysis of cell functions and cell activities. FCM offers great potential for investigations in the areas of fish haematology, pathology and immunology because multiparameter measurements of single cells are easily and rapidly performed.

Immunologists routinely used FCM to characterize phenotypically the leukocyte subpopulations. So far, in fish, only a few number of antibodies directed against surface markers are avalaible. The panel of monoclonal antibodies which could identify different subpopulations of fish leukocytes is limited (Deluca et al. 1983; Koumans et al. 1994; Slierend recht et al. 1995) and unfortunately the existing markers display no cross reactivity between fish species. Even though flow cytometric immunophenotyping of fish cells presents a limited interest, FCM offers real advantages over traditional methods. FCM measurements are made on the individual cell and not on the whole population and morphologic, biochemical and functional characteristics can be analyzed simultaneously. Thus it is possible to correlate the cell function or activity with one subpopulation.

While in mammals FCM has been used for long, in fish, only a few such studies have been performed. Recently a battery of assays have been developed to monitor different aspects of the rainbow trout (RBT) cellular immune response (Voccia et al. 1994; Chilmonczyk et al. 1995; 1997). The present paper describes some FCM methods we have developed for the investigation of functional aspects of the RBT cell defense mechanisms.

Fish

\section{Materials and Methods}

Leukocytes were collected from healthy (control) or experimentally infected rainbow trout (Oncorhynchus mykiss - RBT). Fish (5-10 g) were subjected to waterborne Viral Haemorrhagic Septicaemia Virus (VHSV) while PKX parasite infections (intraperitoneal injection) were performed on $30 \mathrm{~g} \mathrm{RBT}$. Control and infected fish were reared in recirculated filtered water thermoregulated at $101^{\circ} \mathrm{C}$ (VHSV infections) or $161^{\circ} \mathrm{C}$ (PKX infections). 
Leukocyte collection

Freshly collected blood anticoagulated with heparin was diluted (1:20) with Minimum Essential Medium (MEM). Cells from pronephros. spleen and thymus were obtained by forcing the tissues through a stainless steel mesh in cold serum-free MEM. Then leukocytes were isolated through a Ficoll cushion. The leukocyte-rich interphase was collected, washed in PBS and resuspended in MEM.

Flow cytometric analysis

Flow cytometric analyses were carried out using a standard fluorescence activated cell analyser (FACScan, Becton Dickinson $)$. For each sample 10000 or 20000 individual cells were recorded using a dotplot combination of low angle forward scattered (FSC) and right angle scattered (SSC) laser light. Data were analysed with the program LY'SIS II version 2.0.

\section{Cell subpopulations}

The autofluorescence emitted by unstained living cells allows the distinction between leukocyte subpopulations according to the size (forward light scatter: FSC parameter) and the cytosolic complexity (side light scatter : SSC parameter) of the cells. The autofluorescence scattering signals are sufficient on their oun to discriminate cells with different morphology: lymphocytes (low FSC / SSC) are accurately differentiated from granulocytes (higher FSC / SSC). Quantification of dead cells was determined by adding propidium iodide (PI) (Sigma) at a final concentration of $5 \mu \mathrm{g} / \mathrm{ml}$ (Deitch et al. 1982).

\section{Phagocytosis}

Phagocytosis assays were performed in vitro as previously described (Chilmonczyk et al. 1995). Briefly, leukocyte suspensions $\left(1.5 \times 10^{6} \mathrm{cells} / \mathrm{ml} \mathrm{MEM}\right)$ were incubated for $18 \mathrm{~h}$ at $16^{\circ} \mathrm{C}$ with fluoresceinated (FITC) latex beads (Polysciences). Leukocytes were incubated with FITC-beads in a proportion of 1 cell for 100 FITCbeads. Non-ingested beads were separated from the phagocytes by centrifuging $(100 \mathrm{~g} \times 10 \mathrm{~min})$ over a cushion of $3 \%$ BSA in PBS. The cell pellet was then resuspended in MEM for flow cytometric measurement. The fluorescence histograms of cell number iersus fluorescence intensity were analysed and phagocytic activity was expressed as the percentage of cells that had ingested at least 3 FITC-latex beads.

\section{Oxidative burst}

Oxidative burst activity was quantified using flow cytometry as a measure of intracellular hydrogen peroxide production as previously described (Chilmonczy k et al. 1997). The assay depends upon the cell incorporation of 2'-7'-dichlorofluorescin diacetate (DCFH-DA), which is a stable nonfluorescent molecule hydrolyzed to DCFH by cytosolic enzymes. Then by the action of $\mathrm{H}_{2} \mathrm{O}_{2}$ produced in leukocytes stimulated with Phorbol Myristate Acetate (PMA), DCFH is oxidised to the fluorescent dichlorofluorescein (DCF). Briefly, isolated PNL (1.5 $\times 10^{6}$ $/ \mathrm{ml}$ ) were resuspended in $1 \mathrm{ml} \mathrm{MEM}$ and incubated for $15 \mathrm{~min}$ at room temperature with DCFH-DA. Cellular baseline of fluorescence (DCF) was determined at this zero time and PMA (10 ng/ml, final concentration) was immediately added and the level of intracellular fluorescence was measured in unstimulated and PMA stimulated cells by flow cytometry. A typical kinetic experiment included the analysis of 10000 individual cells analysed from the same tube sample $5,15,30,45$ and 60 min over the reaction period. At each sampling time. a stimulation index was determined as the ratio of fluorescence of PMA stimulated cells to that of unstimulated cells.

\section{Nonspecific Cytotoxic Cells (NCC)}

We have adapted to RBT the method of Chang et al. (1993) using the mouse lymphoma YAC-1 cell line (Kiessling et al. 1975) as target cells. The assay is based on the simultaneous expression of 2 fluorescent signals allowing the discrimination between a) unstained effector cells. b) green fluorescent viable target cells c) red plus green fluorescent dead target cells. Target cells are labeled with a green fluorescent dye: 3, 3'dioctadecyloxacarbocyanin perchlorate (DIO-C18), a lipophilic carbocyanine membrane dye. Target cells are incubated with RBT leukocytes at a effector - target ratio of $50: 1$ for $2 \mathrm{~h}$ at $20^{\circ} \mathrm{C}$ in presence of propidium iodide which permeates only through the membrane of dead cells and stains the nucleic acids emiting a red fluorescence. FCM acquisitions are performed on the base of green and red fluorescence parameters displayed by target cells: dead and damaged target cells appear doubly stained. Only the target cells, which are easily distinguished from an abundance of effectors by their distinct green stable fluorescence, are considered in the aquisition of data.

\section{Results}

\section{FCM characterization of leukocyte subpopulations}

Using the autofluorescence of unstained cells, FCM allows a clear delineation of cell subpopulations. In RBT the flow cytometric profiles of cell populations, designed by a twoparameter cytogram using FSC versus SSC (dot plot representation), are representative of the organ from which the leukocytes originated. Each lymphoid organ displays a characteristic cytogram pattern. Spleen and thymus cell populations are for the most part composed of lymphocytes while pronephros leukocytes display 3 populations (lymphocytes, monocytes and granulocytes). In blood the situation is less obvious, blood 
leukocytes are generally characterized by 2 major populations (lymphocytes and granulocytes), however, blood cytograms may differ greatly between fish. Depending upon experimental and/or pathological conditions, strong modifications may occur and the aspect of the dotplot profiles diverges from that of the characteristic cytogram representative of each lymphoid organ (Table 1). During the acquisition of the data cell viability is easily recorded using propidium iodide which stains specifically the DNA of dead cells.

Electronic gating allows the selection of populations of interest, or the exclusion from aquisition of unwanted population, cell debris or dead cells.

Table 1

Variability occurring in the aspect of the FCM cytograms of pronephros leukocytes. Compared to the regular pattern displayed by control RBT, fish subjected to pathogens (VHSV or PKX) or to a crowding stress presented highly modified cytogram patterns.

\begin{tabular}{|cc|c|}
\hline $\begin{array}{c}\text { PN Leukocytes } \\
\text { from }\end{array}$ & \multicolumn{2}{c|}{ Cytogram pattern } \\
& regular & modified \\
\hline Control & $88 \%(128 / 145)$ & $12 \%(17 / 145)$ \\
VHSV infected & $60 \%(25 / 42)$ & $40 \%(17 / 42)$ \\
PKX infected & $6 \%(6 / 92)$ & $94 \%(86 / 92)$ \\
Stressed & $41 \%(10 / 24)$ & $59 \%(14 / 24)$ \\
\hline
\end{tabular}

Phagocytosis

FCM assessment of phagocytic activity is based on the determination of cells engulfing fluorescent (FITC)-latex beads. This method allows a clear delineation between phagocytic and non-phagocytic cell populations on the basis of fluorescence parameters.

Phagocytosis assays were carried out on leukocytes collected from the main RBT lymphoid organs including the thymus. In RBT the pronephros is the main phagocytic organ. A slight but not negligible number of active phagocytes occur in the thymus (Table 2). Our data show that the phagocytosis ability may differ greatly between fish (Table 3 ).

Table 2

FCM assessment of phagocytosis in leukocyte populations of $8 \mathrm{RBT}$ fingerlings. $\% \pm \mathrm{SD}$ of cells having ingested 3 or more FITC-latex beads.

\begin{tabular}{|c|c|c|c|}
\hline Pronephros & Blood & Spleen & Thymus \\
\hline $12.2 \pm 5.1$ & $6.1 \pm 3.1$ & $6.7 \pm 3.9$ & $1.1 \pm 0.5$ \\
\hline
\end{tabular}

Table 3

FCM assessment of phagocytosis ( $\%$ of phagocytes having ingested 3 and more FITC-latex beads) and oxidative burst (increase of mean of fluorescence intensity after PMA activation).

Both assays were performed on pronephros cells from the same trout and \% of granulocytes was recorded from unstained pronephros leukocyte population.

\begin{tabular}{|c|c|c|c|}
\hline RBT & $\begin{array}{c}\text { Pronephros } \\
\text { granulo. (\%) }\end{array}$ & $\begin{array}{c}\text { Phagocytic } \\
\text { activity }(\%)\end{array}$ & $\begin{array}{c}\text { Ox. Burst } \\
(15 \mathrm{~mm} \text { PMA) }\end{array}$ \\
\hline 1 & 60.4 & 20.3 & 77.8 \\
2 & 32.9 & 12.6 & 52.9 \\
3 & 51.6 & 19.1 & 65.4 \\
4 & 58.6 & 15.6 & 85.1 \\
5 & 20.4 & 9.1 & 13.9 \\
6 & 37.9 & 16.1 & 49.7 \\
\hline
\end{tabular}




\section{Oxidative burst}

The assay allows the estimation of intracellular production of hydrogen peroxide in PMA stimulated cells. The fluorescence measured by the flow cytometer is proportional to the amount of $\mathrm{H}_{2} \mathrm{O}_{2}$ produced by the cells. A typical experiment includes the kinetic analysis of $10^{4}$ individual cells at 5,15 and 45 min post PMA stimulation. The results are expressed as the difference between the mean fluorescence produced by PMA stimulated cells and unstimulated cells. As the assay requires a small amount of cells, comparative analysis of phagocytosis and oxidative burst activity are easily performed. In addition, the data recorded from the analysis of cell functions can be correlated with one cell subpopulation. Table 3 shows that pronephros in which the granulocytes constitute the major fraction of the leukocytes are characterized by a high phagocytic activity and a strong oxidative burst (RBT 1 and 4). Inversely a minor fraction of granulocytes display a lower phagocytosis and a very weak oxidative burst (RBT 5).

\section{Nonspecific Cytotoxic Cells}

NCC activity was demonstrated in the main lymphoid tissues of RBT (Table 4). Cytotoxic effector cells have been mostly demonstrated in pronephros than in blood and spleen which both displayed similar level of killing activity. A significant activity was also measured in the thymus.

The modulation of NCC activity under pathologic conditions was assayed in trout experimentally infected with PKX the parasite causative of the Proliferative Kidney Disease. FCM evaluation of NCC activity was compared between healthy control trout and PKX parasited fish. Infected trout were sampled at 3 different periods during the course of the disease: a) at the beginning, b) in the acute phase, c) in recovering fish (Table 5). Compared to controls, infected trout displayed neither impairment nor enhancement of NCC activity. Tables 4 and 5 show that percentage of cytotoxicity may vary considerably between individual fish. This large inter-fish variability causes difficulties in the interpretation of the data.

Table 4

FCM assessment of NCC activity: \% \pm SD of target cells (YAC-1) lysis occurring in blood and lymphoid organs of 8 RBT.

\begin{tabular}{|c|c|c|c|}
\hline Blood & Pronephros & Spleen & Thymus \\
\hline $12.4 \pm 6.2$ & $25.3 \pm 7.9$ & $15.8 \pm 5.6$ & $11.2 \pm 6.2$ \\
\hline
\end{tabular}

Table 5

Modulation of NCC activity in PKX infected fish. \% \pm SD of target cell lysis occurring in pronephros (PN) and spleen was compared between control and $\mathrm{PKX}$ infected trout sampled at different time during the course of the disease. $A=$ beginning of the infection; $B=$ acute phase of the disease; $C=$ recovering fish

\begin{tabular}{|c|c|c|c|c|}
\hline & \multirow{2}{*}{$\begin{array}{l}\text { Control } \\
(\mathrm{n}=12)\end{array}$} & \multicolumn{3}{|c|}{ PKX infected RBT } \\
\hline & & $\mathbf{A}(\mathrm{n}=8)$ & B $(n=10)$ & $C(n=8)$ \\
\hline \multirow{2}{*}{$\mathrm{PN}$} & 23.4 & 21.8 & 21.2 & 27.6 \\
\hline & \pm 11.5 & \pm 8.8 & \pm 15.1 & \pm 13.1 \\
\hline \multirow{2}{*}{ Spleen } & 15.4 & 9.3 & 21.4 & 13.4 \\
\hline & \pm 8.6 & \pm 4.9 & \pm 7.3 & \pm 3.6 \\
\hline
\end{tabular}

\section{Discussion}

Immunologists routinely used FCM to characterize phenotypically the leukocyte subpopulations. Unfortunately, in trout hitherto only a few number of antibodies directed 
against surface markers are avalaible (Deluca et al. 1983; Slierendrecht et al. 1995). Because of the lack of phenotypic markers the study of the fish cellular immune response involves the screening of morphological characteristics and functional mechanisms. Such combined analysis is easily performed using a flow cytometer. FCM offers a real advantage over conventional techniques because useful informations related to the leukocyte subpopulations are easily provided by the flow cytometer. In spite of the paucity of cell markers, interesting data are obtained from the direct study of non-labeled cells, on the basis of cell autofluorescence. These morphometric informations are very useful. Thus the heterogeneity occurring in the cytogram profiles is correlated with the health status of the fish. This heterogeneity could represent a significant part of the inter-fish variability occurring in the results.

Phagocytosis has been described to play a major role in fish defense mechanisms. The phagocytic system, mechanisms of phagocytosis and killing activity have been described and comprehensively reviewed (MacArthur et al. 1985; Secombes and Fletcher 1992). In mammals, assessment of phagocytosis by FCM has been used for long (Dun and Tyrer 1981; Bjerknes and Bassoe 1983).

More recently in fish, FCM in vitro phagocytosis assays have been developed to assess the modulation of immune response by pathogens (Chilmonczyk 1995), xenobiotics (Voccia et al. 1994; 1997) or both (Chilmonczyk et al. 1997). It is possible to run a phagocytosis assay with a small number of cells $\left(2 \times 10^{5}\right)$. This is a real advantage allowing in vitro kinetic studies and sampling of small fish.

Oxidative mechanisms represent an important part of the intracellular microbicidial activity involving a variety of toxic oxygen species produced by activated phagocytes. The associated activity which results from the activation of NADPH oxidases is known as the oxidative or respiratory burst. The FCM technique we have developed, allows an accurate estimation of the capacity of cells to undergo an oxidative burst in response to a variety of stimuli. Oxidative burst assays are commonly used in immunotoxicology and immunopathology to study the modulations of cell defense mechanisms by pollutants, toxicants or pathogens (Chilmonczyk et al. 1997; Voccia et al. 1994; 1997). As in phagocytosis assays, only a number small of cells is needed to assess the oxidative burst. This allows the possibility of performing both assays in parallel on the same cell sample (Table 3).

NCC are considered as the fish equivalent of mammalian natural killer (NK) cells (Evans and J a so-Friedmann 1992). NCC activity has been demonstrated in several fish species including catfish (Evans et al. 1984) shark (Mc Kinney et al. 1986), RBT (Hay den and Laux 1985; Greenlee et al. 1991; Ristow et al. 1995) or carp (Suzumura et al. 1994). NCC activity was demonstrated in the main lymphoid tissues of RBT (Table 4). The activity measured in the thymus confirms previous observation (Hayden and Laux 1985). This wide-spread cytotoxic activity suggests that a substantial part of the nonspecific defense mechanisms could be due to NCC.

NCC flow cytometric assay has the advantage of being able to detect dead target cells before lysis, thus the incubation time required to detect killing is shorter than in conventional radioactive assay. Our data show that levels of cytotoxicity varied considerably between individual fish. In this particular case the large inter-fish variability could be due, in part, to non-adequate (because of mammalian origin) target cells. The use of fish target cell should improve the accuracy of the NCC assay.

So far, in fish, only a few FCM studies have been performed even though FCM offers great potential for the study of the fish immune cells. The functional assays we have developed to assess phagocytosis, oxidative burst and NCC activity, have proven to be accurate and 
reliable tests. Compared to conventional methods, the use of FCM presents obvious advantages. FCM is a very sensitive method that allows rapid multiparameter analysis of single cells and evaluation of cell functions. FCM assays require much less cells per analysis and are more rapid than conventional assays, thousands of cells can be analyzed within a few seconds.

A large number of fluorescent dyes used in mammalian models are suitable for investigations in fish. Thus flow cytometer emerges as a useful tool to study haematopoietic cells and cellular activity.

\section{Buněčná imunitní odpověd u pstruha duhového (Oncorhynchus mykiss): studie pomocí průtokové cytometrie}

Pozornost byla věnována vývoji metod vhodných pro studium nespecifických buněčných obranných mechanismů u pstruha duhového: fagocytóza, aktivita respiračního vzplanutí a nespecifická cytotoxicita. Při srovnání s konvenčními metodami je průtoková cytometrie rychlou, vhodnou a reprodukovatelnou metodou pro analýzu rybích buněčných imunitních funkcí. Vedle hodnocení obranných mechanismů jsou prezentovány i údaje z pozorování nebarvených buněk. Průtokové cytometrické profily buněk jsou reprezentativní pro orgán, z něhož leukocyty pocházejí. Každý lymfoidní orgán má svůj charakteristický cytogram. Průtoková cytometrie se ukazuje jako vhodný nástroj ke studiu imunitních reakcí a patologických procesů.

\section{References}

BASSOE, C. F., LAERUM, O. D., SOLBERG, C. O., HANEBERG, B. 1983: Phagocytosis of bacteria by human leukocytes measured by flow cytometry. Proc. Soc. Exp. Biol. Med. 174: 182-186

BJERKNES. R.. BASSOE, C. F. 1983: Human leukocyte phagocytosis of zymosan particles measured by flow cytometry. Acta. Pathol. Microbiol. Immune Scand. 91: 341-348

CHANG. L.. GUSEWITCH. G. A., CHRITTON, D. B. W., FOLZ, J. C., LEBECK, L. K., NEHLSENCANNARELLA, S. L. 1993: Rapid flow cytometric assay for the assessment of natural killer cell activity. J. Immunol. Methods 166: 45-54

CHILMONCZYK. S., VOCCIA, I., MONGE. D. 1995: Pathogenesis of viral haemorrhagic septicemia virus: cellular aspects. Vet. Res. 26: 501-511

CHILMONCZYK, S., VOCCIA, I., TARAZONA, J. V., MONGE, D. 1997: Flow cytometric analysis of fish leucocyte populations exposed to pollutants and pathogens: modulatory effects induced by experimental procedures. In: Zelikoff, J. T. (ed.) Ecotoxicology: Responses, Biomarkers and Risk Assessment. OECD by SOS Publications, Fair Haven, NJ, pp. 171-184

DEITCH, A. D., LAW, H., DEVERE-WHITE. R. 1982: A stable propidium iodide staining procedure for flow cytometry. J. Histochem. Cytochem. 30: 967-972

DELUCA, D.. WILSON, M., WARR, G. W. 1983: Lymphocyte heterogeneity in the trout, Salmo gairdneri, defined with monoclonal antibodies to IgM. Eur. J. Immunol. 13: 546-551

DUNN, P. A.. TYRER, H. W. 1981: Quantification of neutrophile phagocytosis, using fluorescent latex beads. Correlation of microscopy and flow cytometry. J. Lab. Clin. Med. 98: 374-381

EVANS, D. L., GRAVES, S. S., COBB, D., DAWE, D. L. 1984: Nonspecific cytotoxic cells of fish (Ictalurus punctatus). II. Parametre of target cell lysis and specificity. Dev. Comp. Immunol. 8: 303-312

EVANS, D. L..JASO- FRIEDMANN, L. 1992: Nonspecific cytotoxic cells as effectors of immunity in fish. Annual rev. of Fish Diseases. 2: 109-121

GREENLEE. A. R., BROWN, R. A., RISTOW, S. S. 1991: Nonspecific cytotoxic cells of rainbow trout (Oncorhynchus mykiss) kill YAC-1 targets by both necrotic and apoptotic mechanisms. Dev. Comp. Immunol. 15: $153-164$

HAYDEN, B. J.. LAUX, D. C. 1985: Cell mediated lysis of murine target cells by nonimmune salmonid lymphoid preparations. Dev. Comp. Immunol. 9: 627-639

KIESSLING. R.. KLEIN, E., WIGZELL, H. 1975: Cytotoxic cells with specificity for mouse Maloney leukemia cells. Specificity and distribution according to genotype. Eur. J. Immunol. 5: 112-117 
KOUMANS-VAN DIEPEN, J. C. E., TAVERNE-THIELE, J. J., VAN RENS, B. T. T. M., ROMBOUT, J. H. W. M. 1994: Immunocytochemical and flow cytometric analysis of B cells and plasma cells in Carp (Cyprinus carpio L.); an ontogenetic study. Fish Shellfish Immunol. 4: 19-28

MACARTHUR, J. I., FLETCHER, T. C. 1985: Phagocytosis in fish. In: Manning, M. J., Tatner, M. F. (eds) Fish immunology. Academic Press, London, pp. 29-46

MCKINNEY, E. C., HAYNES,L.. DROESE,A. L. 1986: Macrophage-like effector of spontaneous cytotoxicity from the shark. Dev. Comp. Immunol. 10: 497-508

RISTOW, S. S., GRABOWSKI, L. D., WHEELER, P. A., PRIEUR, D. T., THORGAARD, G. H. 1995: Arlee line of rainbow trout (Oncorhynchus mykiss) exhibits a low level of nonspecific cytotoxic cell activity. Dev. Comp. Immunol. 19: 497-505

SECOMBES, C. J., FLETCHER, T. C. 1992: The role of phagocytes in the protective mechanisms of fish. Ann. Rev. Fish Diseases. 2: 53-71

SLIERENDRECHT, W. J., LORENZEN, N., GLAMAN, J., KOCH, C., ROMBOUT, J. H. W. M. 1995: Immunocytochemical analysis of a monoclonal antibody specific for rainbow trout (Oncorhynchus mykiss) granulocytes and thrombocytes. Vet. Immunol. Immunopathol. 46: 349-360

SUZUMURA, E., KURATA, O.. OKAMOTO, N., IKEDA,Y. 1994: Characteristics of natural killer-like cells in carp. Fish Pathol. 29: 199-203

VOCCIA, I., KRZYSTYNIAK, K., FLIPO, D., FOURNIER, M. 1994. In vitro mercury-related cytotoxicity and functional impairment of the immune cells of rainbow trout (Oncorhyncus mykiss). Aquat. Toxicol. 29: 37-48

VOCCIA, I., SANCHEZ-DARDON, J., DUNIER, M., CHILMONCZYK, S., FOURNIER, M. 1997: Contaminants on competence of rainbow trout macrophages. In : Chemically induced alteration in functional development and reproduction of fish, Setac Press, pp. 99-109 